\title{
MICROSTRUCTURE , FATTY ACIDS PROFILE , CHEMICAL COMPOSITION AND ORGANOLEPTIC PROPERTIES OF LOW - FAT GOUDA -LIKE CHEESE DURING RIPENING
}

\author{
EL-NIMER, AMAL M. M.; H. H. OMAR; M. A. AHMED and M. A. MOSTAFA \\ Dairy Technology Department, Animal Production Research Institute, ARC, Dokki, \\ Giza, Egypt. \\ amal_elnemr@yahoo.com
}

(Manuscript received 2 October 2017)

\begin{abstract}
$\mathrm{L}$ ow - Fat Gouda- like cheese (LFC) was manufactured under the Egyptian condition to study the effect of adding either Simples $\AA-100$, or microbial Transglutaminase (mTGase) to cheese milk on the gross chemical composition, fatty acids profile (FAP), microstructure and organoleptic properties of the resultant cheese, during 90 days of ripening. Eight treatments were made from cow's milk; one of these treatments served as control, $3 \pm 0.1 \%$ fat $(\mathrm{C} 1)$. The other seven treatments were made from milk standardized to $1.5 \pm 0.1 \%$ fat, one of them served as control 2 (C2) and the three treatments were made with adding Simples $®-100$, at a rate of $0.2,0.4$ and $0.6 \mathrm{~g} / 1$ liter of milk, whereas the other three treatments were made with adding mTGase at a rate of $0.3,0.5$ and $0.8 \mathrm{~g} / 1$ liter of milk. Results revealed that fat reduction in cheese milk, increasing the moisture, $\mathrm{pH}$ values, protein and salt on dry matter basis ( $P / D M \& S / D M$ ) ; and decreasing the cheese yield, acidity, fat on dry matter basis and cheese ripening indices in the resultant LFC, in fresh and ripened cheeses. It also affected the fatty acids profile by increasing the total saturated fatty acids (TSFA) and decreasing the total unsaturated fatty acids (TUSFA). The microstructure of LFC was characterized by considerably few vacuoles or voids, more dense and extensive protein matrix, reducing the coalescence of fat globules, and translucent appearance. Addition of fat replacer (FR) or (mTGase) to cheese milk had an apparent effect on the chemical composition and yield; fatty acids profile; microstructure and organoleptic properties of the resultant LFC. So it increased the moisture, P/DM, acidity, cheese ripening indices and yield. Moreover, it increased the total of SFA and USFA in both fresh and ripened cheeses as well as the SFA / TFA ratios. There is a direct relationship between the level of FR or mTGaseadded and the concentrations of both SFA or USFA in fresh or ripened cheeses. FR or mTGase, furthermore, improved much the microstructure and organoleptic properties (especially its body \& texture) of the resultant LFC.

Key words: Gouda cheese, Low Fat, Full-Fat, Simples $₫-100$, TGase, FFA, SFA, USFA, microstructure.
\end{abstract}

\section{INTRODUCTION}

Gouda cheese is a yellowish cheese named after the city of Gouda in Netherland; it is one of the primary Dutch type cheese varieties produced worldwide. 
It is manufactured from cows, goats, or sheep's milk and characterized by yellow color ; smooth , compact , crumbly, dense and spring texture ; creamy, nutty and sweet flavor ( aroma is pungent ). Usually, it is ripened for 1-6 months depending on the required characteristics, the demand of consumers and the economic factors. Gouda cheese accounting for $50-60 \%$ of the world's cheese consumption.

Increased awareness of people on fitness and healthy life style has led to an increased demand for low-calorie foods in particular for low and reduced fat cheese (Konkular et al., 2004). Fat reduction, however, represents a challenging problem because fat is important for texture and flavor of many dairy products such as cheeses (Mistry, 2001). Fat reduction in hard and semi-hard cheeses resulted in firm body and texture, lack of flavor, and/or presence of off-flavors.

Fat replacers are of low calorie and providing some of the functional properties of the fat. They are divided into 2 groups: fat substitutes and fat mimetic, fat substitutes are non polar, fat soluble compounds, providing sensory and functional properties of fats to food, while fat mimetic are polar, water soluble substances and used to partially replace some of sensory and functional characteristics of fat. Fat mimetic capable to bind water and thereby improving the texture and yield of the lowfat cheese (Mistry, 2001).

Various techniques were used to improve the texture of low and reduced fat cheeses include manufacturing process modifications, use of special starter cultures, fat replacers, stabilizers and enzymes e.g. Transglutaminase. In recent years, Transglutaminase (TGase) has been used by many researchers. It present naturally in most of animal tissues, body fluids, fish, plants and microorganisms. Microbial transglutaminase (mTGase ) is $\mathrm{C}^{++}$independent, shows a lower substrate specificity , low cost mass production and now is widely spread as functional enzyme within various batches of food industry. mTGase can form both inter and intra - molecular iso-peptide bonds between many types of proteins by cross-linking of the amino acid residues of glutamic and lysine.

An understanding of microstructure provides knowledge of how texture develops in cheese during ripening, and allows changes to the manufacturing process with more predictable results for the quality of the finished cheese. The state of water (bound, entrapped or bulk) the state of fat (globular or pools trapped within voids in the protein matrix), the extent of protein association (through calcium phosphate bonds or hydrophobic interaction), the $\mathrm{pH}$, and the mineral and ionic balance (especially sodium chloride and calcium ), all play important roles in developing cheese microstructure (Tamime, 2007). The microstructure of cheese consists of a complex arrangement of fat and protein aqueous phases. Chymosin coagulated 
cheeses are characterized by thin protein fibers whereas acid- heat gels contain thicker fibers. Understanding cheese microstructure is not only important for creating desirable texture from the perspective of the consumers, but also for creating an environment where good flavor is not precluded. Cheese is stated to have a macrostructure, which includes the curd granule structure, and a microstructure consisting of those structural elements that are only visible by microscope.

This work was done to study the effect of adding fat replacer (simples $®-100$, ) or mTGase enzyme to cow's milk, on the chemical composition, fatty acids profile, microstructure and organoleptic properties of the resultant low-fat Gouda-like cheese, during ripening .

\section{MATERIALS AND METHODS}

\section{Materials:-}

Chemicals: used in this study were of analytical grade, supplied by BDH, Sigma and Prolabo chemical companies.

Milk: fresh cow's milk was obtained from the herd of Sides experimental station, Animal Production Research Institute, Egypt.

Fat replacer: Simples $₫-100$, protein- based fat replacer was obtained from CP KIco, Chicago, 11, USA (chemical composition was $40 \%$ moisture, $<7 \%$ ash and $35.9 \%$ carbohydrate).

Transglutaminase: A Ca-independent microbial transglutaminase (ACTIVA MP, with activity of 100 units $/ g$ powder) was obtained from Ajinomoto Europe Sales Gmbh , Hamburg , Germany .

Salt: From El - Nasr company, Alexandria, Egypt.

Rennet and starter culture: Hansen's powder rennet and Lactococcus lactis sub sp. Lactis were obtained from CHr- Hansen's Laboratories, Copenhagen, Denmark.

\section{Cheese making:}

Eight treatments of Gouda cheese were made as follows;

1 - Full-fat cheese was made from cow's milk ( $3 \pm 0.1 \%$ fat) and served as control (Group 1).

2 - Low-fat cheese made from cow's milk (1.5 $\pm 0.1 \%$ fat) without any addition Control (Group 2).

3 - Low-fat cheese was made from cow's milk $(1.5 \pm 0.1 \%$ fat $)+0.2,0.4$ and $0.6 \mathrm{~g}$ Simples $®-100$, /L milk (treatments $S_{1} . S_{2}$ and $S_{3}$, respectively).

4 - Low-fat cheese was made from cow's milk $(1.5 \pm 0.1 \%$ fat $)+0.3,0.5$ and 0.8 gmTransglutaminase /L milk (Treatments G1, G2 , and G3 , in order). 
Milks containing mTransglutaminase were incubated at $40^{\circ} \mathrm{C} / 60 \mathrm{~min}$. before renting. Milk of all treatments was heat treated at $73 \mathrm{C}^{\circ} / 20 \mathrm{sec}$., cooled to $32 \mathrm{C}^{\circ}$, $\mathrm{Cacl} 20.02 \%$ ) and $1 \%$ starter culture were added. Gouda cheese was made according to Scott (1981) method and ripened at $10-12 C^{\circ}$ for 3 month at relative humidity of $85 \%$. Samples were taken when fresh and after 3 month of ripening for analysis.Three replicates of these treatments were done.

\section{Methods of analysis:-}

Chemical analysis:Titratable acidity, moisture, fat and total protein were determined according to Ling (1963). Water soluble nitrogen and non protein nitrogen were determined according to IDF (1993).pH of cheese samples was determined using an Accumet model $\mathrm{pH}$ meter (HANNA instruments $\mathrm{H}$ 1848).

Free fatty acids profile: Total cheese lipids were extracted according to the methods A.O.A.C. (2000). Free fatty acids (FFA) concentrations of cheese samples were quantified using gas chromatograph (17A-GC, Shimadzu Co., Japan) equipped with a fused silica capillary column (60 m length x 0.25 mmi.d. x0.2 u m; SP 2380, Supelco Inc., Bellfonat, PA) with a flow ionization detector (FID).Oven temperature was programmed from $50^{\circ} \mathrm{C}$ to $250{ }^{\circ} \mathrm{C}$ at a rate of $4{ }^{\circ} \mathrm{C} / \mathrm{min}$, with initial and final hold times of 2 and $10 \mathrm{~min}$. Injector and detector temperatures were 220 and $250{ }^{\circ} C_{\text {, }}$ respectively. The injection mode was split injections, and volume was UL. The carrier gas was helium at a rate of $2 \mathrm{~mL} / \mathrm{min}$.

\section{Electron Microscopy of cheese:}

The Electron Microscopic analysis was performed in the Egyptian Mineral Resources Authority Central Laboratories Sector. The Scanning Electron Microscope (SEM) for Gouda like cheese was carried out using SEM (FEI company, Netherlands) Model Quanta 250 FEG (Field Emission Gun) attached with EDX Unit (Energy Dispersive X-ray Analysis), samples were freeze- fractured in liquid nitrogen to approximately $1-\mathrm{mm}$ pieces and these pieces were then mounted on aluminum stubs with silver paint, dried to critical point and coated with gold for $300 \mathrm{~s}$ in a sputterCoater (SCD 005). Sputter Coater and scanned under low vacuum condition with pressure chambers 60 pa. (Karami et al., 2009).

\section{Organoleptic Properties:}

Samples (from fresh and 90 days ripened cheeses) were scored for Organoleptic Properties according to the scoring sheet suggested by Abdel Fattah (1966). Scoring was carried out by staff members at Department of Dairy Technology, Animal Production Research Institute, Ministry of Agriculture. 


\section{RESULTS AND DISCUSSION}

\section{Chemical composition :}

\section{A-Fat reduction :}

Results indicated that fat reduction of cheese milk by approximately $50 \%$, resulted in increasing the moisture, $\mathrm{pH}$ values, protein and salt on dry matter basis ( $P / D M \& S / D M)$ and decreasing the cheese yield, acidity, fat on dry matter basis ( F/DM) and cheese ripening indices soluble nitrogen on total nitrogen ( SN/TN ) and non protein nitrogen on total nitrogen (NPN/TN) in the resultant low-fat (LFC) Gouda-like cheese (treatment C2) compared to full fat (FFC) cheese (treatment C1), when fresh or after 3 months of ripening (Tables $1 \& 2$ ).

\section{B- Fat replacer or mTransglutaminase :}

Addition of fat replacer (FR) or mTransglutaminase (mTGase ) to cheese milk had an apparent effect on the chemical composition and yield of the resultant low-fat cheese (treatment, C2), so it increased the moisture, P/DM, acidity, cheese ripening indices and yield compared to the resultant LFC and FFC, when fresh and after ripening. The availability of low molecular weight peptides needed for the growth and activity of bacteria was decreased due to the raised cross- linking bonds which may explain the slow growth rate and activity of the starter. This explained the slow rate of acid production noticed in mTGase treated cheeses ( $\mathrm{G} 1, \mathrm{G} 2$, and G3 ), compared to the other ones. These results are in agreement with that found by (Konuklar et al., 2004) who found that low-fat cheese made with protein-based or Nutria ( beta- glucan hydrocolloial ) had $2.2-2.3 \%$ higher moisture, protein and salt contents than the control cheese.

Results, also, showed a direct relationship between level of FR or mTGase used and former parameters determined, along the ripening period. mTGase treatments had higher degree of proteolysis than the other ones, during ripening. Yanan et al., (2013) found that addition of mTGase to cheese milk increased water content, cheese yield and the proteolysis of cross-linked cheese after 35 days of ripening.

With the advancing of ripening period, P/DM , S/DM acidity, F/DM and proteolysis were increased at the end of the ripening period, whereas moisture and $\mathrm{pH}$ values were decreased in all treatments as a result of evaporation and the action of the biochemical interactions took placed. These findings were demonstrated by El- Abd et al., (2010). 
Table 1. Changes in chemical composition and yield of low-fat Gouda-like cheese, when fresh and after three months of ripening period.

\begin{tabular}{|c|c|c|c|c|c|c|c|c|}
\hline \multirow{3}{*}{$\begin{array}{l}\text { Ripening } \\
\text { period } \\
\text { (months) }\end{array}$} & \multirow{3}{*}{$\begin{array}{c}\text { Full fat } \\
\text { cheese } \\
C_{1}\end{array}$} & \multirow{3}{*}{$\begin{array}{l}\text { Low-fat } \\
\text { cheese } \\
\mathrm{C}_{2}\end{array}$} & \multicolumn{6}{|c|}{ Treatments } \\
\hline & & & \multicolumn{3}{|c|}{ Simples $®-100$, } & \multicolumn{3}{|c|}{ mTransglutaminase } \\
\hline & & & $S_{1}$ & $\mathrm{~S}_{2}$ & $\mathrm{~S}_{3}$ & $\mathrm{G}_{1}$ & $\mathrm{G}_{2}$ & $\mathrm{G}_{3}$ \\
\hline \multicolumn{9}{|c|}{ Moisture (\%) } \\
\hline Fresh & 46.75 & 46.82 & 47.80 & 48.52 & 49.66 & 46.72 & 48.16 & 48.46 \\
\hline 3 & 39.80 & 41.68 & 42.07 & 43.56 & 44.34 & 41.22 & 43.18 & 43.46 \\
\hline \multicolumn{9}{|c|}{ F/DMS (\%) } \\
\hline Fresh & 43.95 & 24.45 & 25.86 & 26.22 & 26.82 & 24.40 & 25.22 & 25.70 \\
\hline 3 & 47.19 & 26.29 & 26.80 & 28.12 & 28.71 & 26.12 & 27.30 & 27.80 \\
\hline \multicolumn{9}{|c|}{ P/DM (\%) } \\
\hline Fresh & 42.89 & 43.69 & 44.72 & 45.30 & 45.90 & 45.55 & 45.90 & 46.80 \\
\hline 3 & 44.50 & 44.78 & 45.86 & 46.63 & 47.42 & 47.43 & 47.92 & 48.53 \\
\hline \multicolumn{9}{|c|}{ S/DM (\%) } \\
\hline Fresh & 3.76 & 3.91 & 4.29 & 4.41 & 4.55 & 4.17 & 4.24 & 4.23 \\
\hline 3 & 5.05 & 5.09 & 5.67 & 5.77 & 5.26 & 5.43 & 5.31 & 5.27 \\
\hline \multicolumn{9}{|c|}{ Yield (\%) } \\
\hline Fresh & 11.48 & 8.83 & 9.24 & 9.65 & 9.85 & 9.57 & 9.82 & 10.12 \\
\hline
\end{tabular}

C1: Full-fat cheese (control 1).

C2: Low-fat cheese (control 2).

S1: Low-fat Simplesse cheese, $0.2 \mathrm{~g} / 1 \mathrm{~L}$ milk.

S2: Low - fat Simplesse cheese, $0.4 \mathrm{~g} / 1 \mathrm{~L}$ milk .

S3: Low-fat Simplessecheese, $0.6 \mathrm{~g} / 1 \mathrm{~L}$ milk .

G1: Low-fat mTransglutaminasecheese , $0.3 \mathrm{~g} / 1 \mathrm{~L}$ milk .

G2: Low-fat mTransglutaminasecheese , $0.5 \mathrm{~g} / 1 \mathrm{~L}$ milk

G3: Low-fat mTransglutaminasecheese, $0.8 \mathrm{~g} / 1 \mathrm{~L}$ mil

F/DM: Fat on dry matter basis .

Tp/DM: Total protein on dry matter basis.

S/DM: Salt on dry matter basis.

Table 2. Changes in Titratable acidity, pH values and proteolysis of low-fat Gouda-like cheese, when fresh and after three months of ripening.

\begin{tabular}{|c|c|c|c|c|c|c|c|c|}
\hline \multirow{3}{*}{$\begin{array}{l}\text { Ripening } \\
\text { period } \\
\text { (months) }\end{array}$} & \multirow{3}{*}{$\begin{array}{c}\text { Full fat } \\
\text { cheese } \\
C_{1}\end{array}$} & \multirow{3}{*}{$\begin{array}{c}\text { Low-fat } \\
\text { cheese } \\
\mathrm{C}_{2}\end{array}$} & \multicolumn{6}{|c|}{ Treatments } \\
\hline & & & \multicolumn{3}{|c|}{ Simples $®-100$, } & \multicolumn{3}{|c|}{ mTransglutaminase } \\
\hline & & & $\mathrm{S}_{1}$ & $\mathrm{~S}_{2}$ & $\mathrm{~S}_{3}$ & $\mathrm{G}_{1}$ & $\mathrm{G}_{2}$ & $\mathrm{G}_{3}$ \\
\hline \multicolumn{9}{|c|}{ Titratable acidity $\quad(\%)$} \\
\hline Fresh & 0.80 & 0.77 & 0.85 & 0.93 & 0.98 & 0.71 & 0.85 & 0.91 \\
\hline 3 & 1.80 & 1.71 & 1.89 & 1.95 & 2.10 & 1.70 & 1.82 & 1.90 \\
\hline \multicolumn{9}{|c|}{$\mathrm{pH}$ values } \\
\hline Fresh & 5.63 & 5.78 & 5.75 & 5.65 & 5.61 & 5.80 & 5.73 & 5.70 \\
\hline 3 & 5.42 & 5.45 & 5.38 & 5.33 & 5.26 & 5.48 & 5.41 & 5.35 \\
\hline \multicolumn{9}{|c|}{ SN/TN (\%) } \\
\hline Fresh & 8.14 & 7.64 & 8.76 & 9.14 & 9.27 & 9.31 & 10.25 & 10.85 \\
\hline 3 & 12.05 & 11.54 & 12.66 & 13.36 & 13.88 & 12.85 & 13.95 & 14.50 \\
\hline \multicolumn{9}{|c|}{ NPN/TN (\%) } \\
\hline Fresh & 3.15 & 2.72 & 3.75 & 3.92 & 4.42 & 4.12 & 4.36 & 4.97 \\
\hline 3 & 4.82 & 3.96 & 5.43 & 5.77 & 5.96 & 5.72 & 6.31 & 6.72 \\
\hline
\end{tabular}

SN/ TN: Soluble nitrogen on total nitrogen basis.

NPN/TN: Non protein nitrogen on total nitrogen basis. 


\section{Fatty acids profile :}

Levels of lipolysis measured as release of free fatty acids (FFA), vary considerably between cheese varieties from moderate ( e.g. Cheddar, Cheshire, Caerphilly ) to extensive ( e.g. mould- ripened, hard Italian and surface bacterially ripened (smear) varieties. The level of lipolysis should not exceed $2 \%$ of triglycerides in Gouda, Gruyere or Cheddar cheeses. Excessive lipolysis is considered undesirable and cheeses of the later varieties containing a moderate level of FFA may be considered as rancid by some consumers (Fox et al., 2004). Limited lipolysis is thought to be desirable in Dutch - type cheeses.

\section{A-Fat reduction:}

Data in Tables (3\&4) revealed that the concentration of total saturated fatty acids (TSFA) in fresh cheese were generally higher in LFC (C2) treatment(38.38) than in FF one , $\mathrm{C} 1$ ( 34.81), whereas the concentration of total unsaturated fatty acids ( TUSFA) were of opposite trend, so it was higher in $\mathrm{C} 1$ (30.79) and lower in C2 (29.87). After 90 days of ripening, the same observations were noticed, being 37.74 in $\mathrm{C} 2$ and 36.56 in C1 for SFA and 33.11 in $\mathrm{C} 1$ and 31.2 in $\mathrm{C} 2$, for USFA

The ratios between TSFA : TUSFA were found higher in C2 (1.29) than in C1 ( 1.12 ), decreased after 90 days of ripening to 1.21 in C2 and 1.10 in C1.

The highest concentrations of SFA noticed in fresh cheeses were to stearic acid C18:0 (14.30), myristic acid C14:0 (9.28) and butyric acid C4:0 ( 4.04 ), whereas the oleic acid C18:1 was the highest USFA $24.91 \mathrm{mg} / \mathrm{kg}$ cheese. The same of observations of predominant SFA were noticed, also, in 90 days of ripened cheeses. Linoleic acid C18:3 was disappeared in both C1 and C2 treatments, at the end of the ripening period. These results were in the same line to that obtained by EL-Abed et al., (2010). Fluctuating the fatty acids concentrations during ripening and disappearing of the others were due to the fatty acids which are the main precursors of the secondary fat-derived compounds such as methyl - ketones, FFAs, aldehydes, lactones and ethyl esters (Leuven et al., 2008 ).

\section{B-Addition of FR or mTGase :}

Addition of FR or mTGase had a pronounced effect on the former parameters determined ( SFA \& USFA) in the part fat reduction (Tables $3 \& 4$ ), so it led to:

1. Increasing the total SFA and USFA in both fresh and ripened cheeses compared to $\mathrm{C} 1$ or $\mathrm{C} 2$ ( in the higher levels only of, S2 and S3 or G2 
and G3 ). The same trend was noticed also approximately in the TFA (SFA + USFA), of all treatments.

Table 3. Free fatty acid profile ( $\mathrm{mg} \mathrm{kg}^{-1}$ cheese) of fresh low-fat Gouda- like cheese containing different levels of Simples $₫-100$, or mTransglutaminase.

\begin{tabular}{|c|c|c|c|c|c|c|c|c|}
\hline \multirow[t]{3}{*}{ Fatty acids } & \multirow{3}{*}{$\begin{array}{c}\text { Full- fat } \\
\text { cheese } \\
C_{1}\end{array}$} & \multirow{3}{*}{$\begin{array}{c}\text { Low-fat } \\
\text { cheese } \\
C_{2}\end{array}$} & \multicolumn{6}{|c|}{ Treatments } \\
\hline & & & \multicolumn{3}{|c|}{ Simples $₫-100, \%$} & \multicolumn{3}{|c|}{ Transglutaminase \% } \\
\hline & & & $\mathrm{S}_{1}$ & $\mathrm{~S}_{2}$ & $\mathrm{~S}_{3}$ & $\mathrm{G}_{1}$ & $\mathrm{G}_{2}$ & $\mathrm{G}_{3}$ \\
\hline \multicolumn{9}{|c|}{ Saturated fatty acids ( SFA) } \\
\hline \multicolumn{9}{|c|}{ Short chain $(<\mathrm{C} 6)$} \\
\hline Butyric C4 & 4.035 & 5.301 & 4.731 & 5.212 & 5.775 & 4.249 & 4.901 & 5.310 \\
\hline \multicolumn{9}{|c|}{ Medium chain ( $\mathrm{C} 6-\mathrm{C} 12)$} \\
\hline Caproic C6:0 & 2.229 & 2.519 & 2.801 & 3.991 & 4.926 & 2.310 & 3.290 & 4.290 \\
\hline Caprilic C8:0 & 0.540 & 1.013 & 0.974 & 1.214 & 1.739 & 0.609 & 1.011 & 1.301 \\
\hline Capric C10:0 & 2.010 & 2.110 & 1.610 & 2.145 & 3.101 & 1.220 & 2.001 & 2.701 \\
\hline Lauric C12:0 & 2.160 & 2.370 & 2.149 & 2.576 & 3.220 & 2.016 & 2.360 & 2.820 \\
\hline \multicolumn{9}{|c|}{ Long chain ( C13 - C22) } \\
\hline Myristic C14:0 & 9.280 & 10.979 & 10.227 & 11.300 & 12.00 & 10.001 & 10.899 & 11.450 \\
\hline Palmitic C16:0 & 0.260 & 0.830 & 0.910 & 1.505 & 1.916 & 0.810 & 1.256 & 1.667 \\
\hline Stearic C18:0 & 14.300 & 13.255 & 13.517 & 14.025 & 14.310 & 13.290 & 13.502 & 13.822 \\
\hline Sum of SFA & 34.805 & 38.377 & 36.919 & 41.968 & 46.987 & 34.504 & 39.22 & 43.361 \\
\hline \multicolumn{9}{|c|}{ Unsaturated fatty acids (USFA) } \\
\hline $\begin{array}{l}\text { Palmitoleic } \\
\text { C16:1 }\end{array}$ & 3.010 & 3.260 & 2.814 & 3.590 & 4.018 & 2.690 & 3.210 & 3.710 \\
\hline Oleic C18:1 & 24.911 & 24.070 & 24.422 & 24.796 & 25.105 & 24.191 & 24.535 & 24.888 \\
\hline Linoleic C18:2 & 2.601 & 2.190 & 2.390 & 2.710 & 3.101 & 2.201 & 2.601 & 3.037 \\
\hline Linolenic C18:3 & 0.450 & 0.345 & 0.390 & 1.710 & 2.425 & 0.355 & 1.224 & 2.001 \\
\hline Sum of USFA & 30.972 & 29.865 & 30.016 & 32.806 & 34.649 & 29.437 & 31.57 & 33.636 \\
\hline $\begin{array}{l}\text { Total fatty } \\
\text { acids }\end{array}$ & 65.777 & 68.242 & 66.935 & 74.774 & 81.636 & 63.941 & 70.79 & 76.997 \\
\hline SFA : USFA & 1.12 & 1.29 & 1.23 & 1.28 & 1.36 & 1.17 & 1.24 & 1.29 \\
\hline SFA / TFA & 52.91 & 56.24 & 55.53 & 56.13 & 57.56 & 53.96 & 55.40 & 56.32 \\
\hline USFA / TFA & 47.09 & 43.76 & 44.47 & 43.87 & 42.44 & 46.04 & 44.60 & 43.68 \\
\hline
\end{tabular}

2. SFA / TFA ratios were found higher in FR or mTGase of fresh treatments than in C2 treatment (low-fat cheese), increased in all treatments after 90 days of ripening. Ratios of SFA/TFA of S2 and S3 treatments (containing the highest levels of FR ) had generally higher values than the other treatments at the end of the ripening period.

3. USFA/TFA values behaved an opposite trend to SFA/TFA, so it were higher in $\mathrm{C} 1$ than in the other treatments, either in fresh or in the ripened cheeses. 90 days mTGase treatments recorded the highest values among treated cheeses compared to C2. Data, moreover, indicated that USFA/TFA were decreased, in fresh and ripened cheeses, as the level of additives increased . 
4. There is a direct relationship between the level of FR or mTGase used and the concentrations of both SFA or USFA in fresh or ripened cheeses.

5. The highest concentrations of SFA noticed were Stearic, Myristic, and butyric acid, while the highest USFA was Oleic acid .

6. The sum of the former 3 fatty acids represented approximately $50 \%$ of the total concentrations of all fatty acids of fresh or ripened cheeses

7. Linolenic acid C18:3 was disappeared from some treated cheeses ( S1 and G1) after 90 days of ripening and this probably was due to their conversion to another fatty acids or to the assimilation process, during lipolysis, by the lipolytic agents such as lipolytic bacteria or heat- resistant lipases.

Table 4. Free fatty acid concentrations ( $\mathrm{mg} \mathrm{kg}^{-1}$ cheese) found in 90 days low-fat Gouda- like cheese containing different levels of Simples $₫-100$, or mTransglutaminase.

\begin{tabular}{|c|c|c|c|c|c|c|c|c|}
\hline \multirow{3}{*}{ Fatty acids } & \multirow{3}{*}{$\begin{array}{c}\text { Full- fat } \\
\text { cheese } \\
C_{1}\end{array}$} & \multirow{3}{*}{$\begin{array}{c}\text { Low-fat } \\
\text { cheese } \\
C_{2}\end{array}$} & \multicolumn{6}{|c|}{ Treatments } \\
\hline & & & \multicolumn{3}{|c|}{ 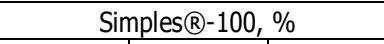 } & \multicolumn{3}{|c|}{ mTransglutaminase } \\
\hline & & & $\mathrm{S}_{1}$ & $\mathrm{~S}_{2}$ & $\mathrm{~S}_{3}$ & $\mathrm{G}_{1}$ & $\mathrm{G}_{2}$ & $\mathrm{G}_{3}$ \\
\hline \multicolumn{9}{|c|}{ Saturated fatty acids (SFA) } \\
\hline \multicolumn{9}{|c|}{ Short chain } \\
\hline Butyric C4 & 3.682 & 4.719 & 4.280 & 4.720 & 5.015 & 3.725 & 4.272 & 4.627 \\
\hline \multicolumn{9}{|c|}{ Medium chain } \\
\hline Caproic C6:0 & 2.180 & 2.275 & 2.310 & 3.122 & 4.010 & 2.186 & 2.773 & 3.495 \\
\hline Caprilic C8:0 & 0.330 & 0.913 & 0.873 & 1.014 & 1.426 & 0.590 & 0.774 & 1.001 \\
\hline Capric C10:0 & 1.621 & 1.733 & 1.442 & 1.895 & 2.690 & 1.009 & 1.623 & 2.091 \\
\hline Lauric C12:0 & 2.240 & 2.168 & 2.187 & 2.855 & 3.422 & 2.099 & 2.464 & 2.991 \\
\hline \multicolumn{9}{|c|}{ Long chain } \\
\hline MyristicC14:0 & 10.210 & 11.230 & 10.656 & 11.892 & 12.810 & 10.357 & 11.376 & 12.267 \\
\hline Palmitc C16:0 & 0.310 & 1.203 & 1.310 & 1.910 & 2.122 & 1.101 & 1.701 & 2.001 \\
\hline StearicC18:0 & 15.991 & 13.501 & 13.899 & 14.210 & 14.509 & 13.501 & 13.799 & 14.099 \\
\hline Sum of SFA & 36.564 & 37.742 & 36.957 & 41.618 & 46.004 & 34.568 & 38.782 & 42.572 \\
\hline \multicolumn{9}{|c|}{ Unsaturated fatty acids (USFA) } \\
\hline $\begin{array}{l}\text { PalmitoleicC16: } \\
1\end{array}$ & 3.604 & 3.680 & 3.310 & 3.899 & 4.424 & 2.910 & 3.855 & 4.132 \\
\hline Oleic C18:1 & 25.901 & 24.590 & 25.680 & 25.827 & 26.110 & 25.001 & 25.490 & 25.890 \\
\hline Linoleic C18:2 & 3.609 & 2.390 & 2.705 & 3.105 & 3.639 & 2.590 & 2.990 & 3.532 \\
\hline Linoleic C18:3 & ----- & ---- & ---- & 2.010 & 2.720 & ---- & 1.790 & 2.703 \\
\hline Sum of USFA & 33.114 & 31.2 & 31.695 & 34.841 & 36.893 & 30.501 & 35.915 & 36.257 \\
\hline $\begin{array}{c}\text { Total fatty } \\
\text { acids (TFA ) }\end{array}$ & 66.384 & 66.465 & 66.652 & 74.474 & 80.595 & 63.26 & 70.753 & 76.698 \\
\hline SFA: USFA & 1.10 & 1.21 & 1.17 & 1.19 & 1.25 & 1.13 & 1.08 & 1.17 \\
\hline SFA/ TFA & 55.08 & 56.78 & 55.45 & 55.88 & 57.08 & 55.12 & 54.81 & 55.51 \\
\hline USFA/ TFA & 49.88 & 46.94 & 47.55 & 46.78 & 45.78 & 48.21 & 47.70 & 47.27 \\
\hline
\end{tabular}

\section{Microstructure :}

The cheese matrix was generally made up of protein network in which fat globules are embedded and voids ( black area) occupied by the water phase (whey) in the cheese. Protein form the major structural network of the cheese (appeared in the micrograph as a grey area) and entrap the fat. 
Chemical composition, proteolysis, lipolysis and water playing a crucial role in the quality and microstructure of cheese (Savello and Ernstrom, 1989).

Microstructure of full and low - fat cheeses ( containing or free from FR or mTGase ) when fresh and after 90 days of ripening are illustrated in Figs. (1- 12).

\section{Fresh cheese :}

\section{A-Fat reduction :}

Fig (1) shows that LF cheese ( C2 treatment) was characterized by considerably few vacuoles or voids, more dense and extensive protein matrix (PM), large stretches of continuous PM interspersed with serum channels ( which may explain the hard and rubbery body \& texture ), reducing the coalescence of fat globules, and translucent appearance (Zammar, 2000 ). The fusion between protein strands was found to be largest in LF cheese which in turn resulted in more compact and less open texture (Badawi et al., 2004).

Fig (1) shows the micrograph of FF cheese (C1), which had PM interspersed liberally with greater numbers of fat globules (Mistry\& Anderson, 1993 ), opaque appearance, large vacuoles or pockets, spongy - like appearance and open texture (Zammar, 2000). There is some debate about whether fat globules participate directly in cheese microstructure by binding to the casein matrix, or act as inert filler material by partially disrupting the casein matrix. Undoubtly, both mechanisms occur to some extent (Michalski et al., 2004 ). The differences observed between FF and LF microstructure of both cheeses were probably due to the manufacturing conditions, the variations in chemical composition and the action of flora.

\section{B- Addition of FR or mTGase :}

Addition of FR Fig. (2) or mTGase Fig (3) improved much the PM and the microstructure of the resultant cheeses compared to LF cheese ( $\mathrm{C} 2$ ), as follows:

-FR increased the openness of cheese structure and exhibited a fibrous structures, spongy - like protein network, more uniform droplets voids, smooth PM, more finely dispersed fat network, and more dense noncontinuous PM (Drake et al., 1997 ; Zammar , 2000 and Konuklar et al., 2004) .

-The appearance was more translucent and the PM had many white parts or areas within it. These white areas were apparent in treatments of lowest concentration. Of FR or mTGase, and decreased in the highest ones. This might 
be due to the action of these additives and its role in retained the water or binding the protein. Tamime (2007) stated that protein and carbohydrate mimetic serve to open up the protein matrix and allow greater moisture retention .

-The size and the number of the voids were found low in the minimum concentration of $\mathrm{FR}$ treatment $\mathrm{S} 1$, became large and much in FR treatment of maximum concentration. On the other hand, mTGase treatments had much small voids in the lower concentration and larger sizes in the highest one .

-It increased the homogeneity of the PM structure, especially in mTGase treatments ( Myllarinen et al., 2007 ).

Fat globules were noticed clearly in low numbers in FR or mTGase treatments than in LF one.

\section{0 days cheeses:}

After 90 days of ripening, the microstructure of all treatments was changed greatly owing to the action of the ripening agents and the altered chemical composition (Figs. 2 \&3). The following points summarized that:

PM was fused more as a result of the dissociation of the casmicelles by the ripening agents resulting in homogeneous and open structure. The rate of fusion was found highest in the maximum concentration of both FR or mTGase treatments S3 and G3 . mTGase had greater PM fusion than FR treatments .

The number and the size of the voids were increased greatly in FR treatments especially in the lowest (S1) and highest (S3) concentrations, compared to the other one (G1 treatment). Anderson and Mistry (1994) stated that some of the void space appeared elongated as a result of ripening because of the complete curd fusion owing to the breakdown of casein matrix They added that this elongation is considered a typical indication of body development in ripening hard and semi- hard cheese .

Appearance was less translucent in all concentrations of FR, while it was more translucent in mTGase treatment G1.

The white areas noticed in fresh cheeses were decreased greatly in all treatments of FR and treatment G3 had the lowest degree of decrease compared to treatment $\mathrm{G} 1$.. 


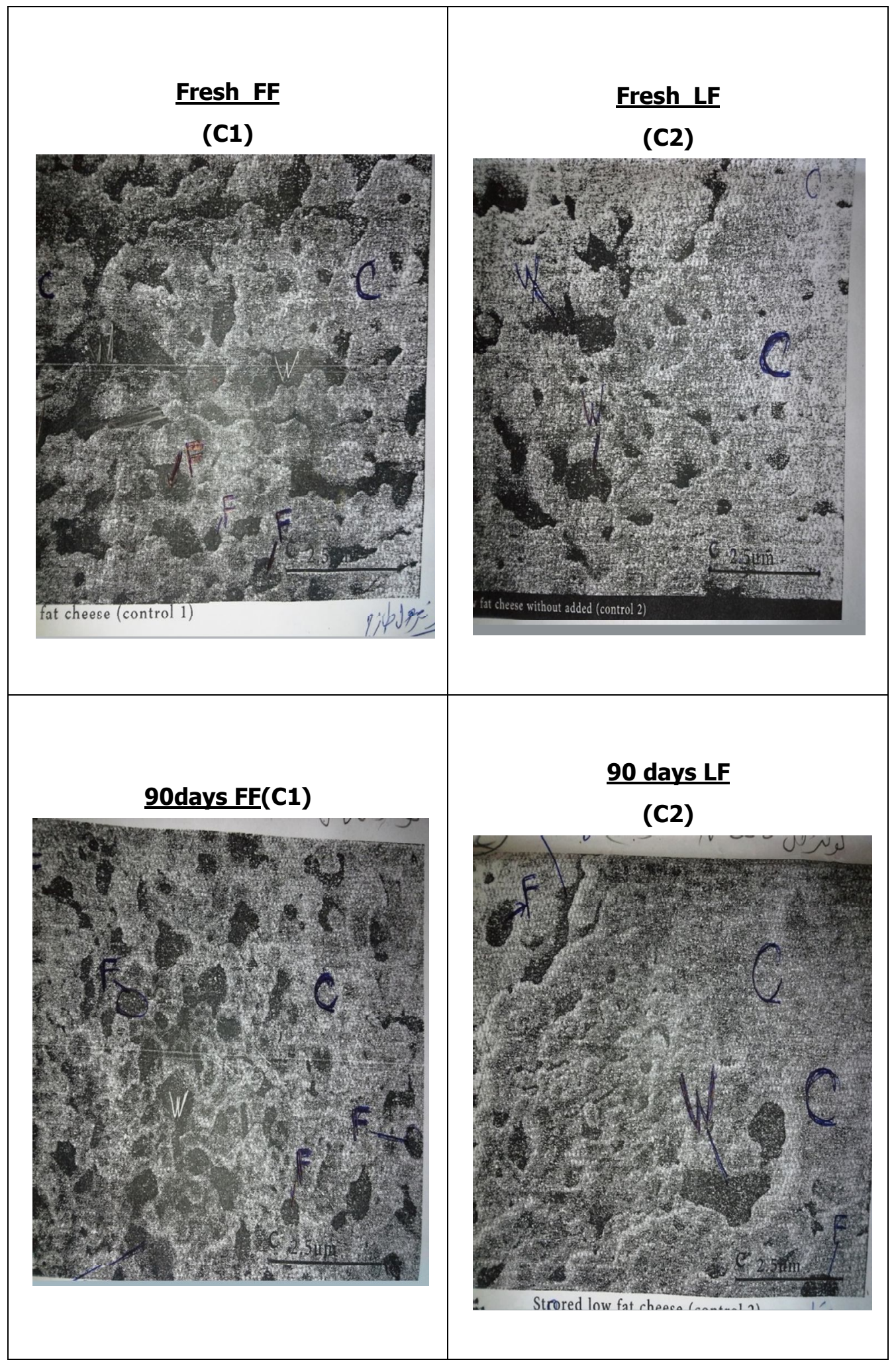

Fig. 1. Micrograph of fresh and 90 days low (LF) and full (FF) - fat Gouda- like cheese. 


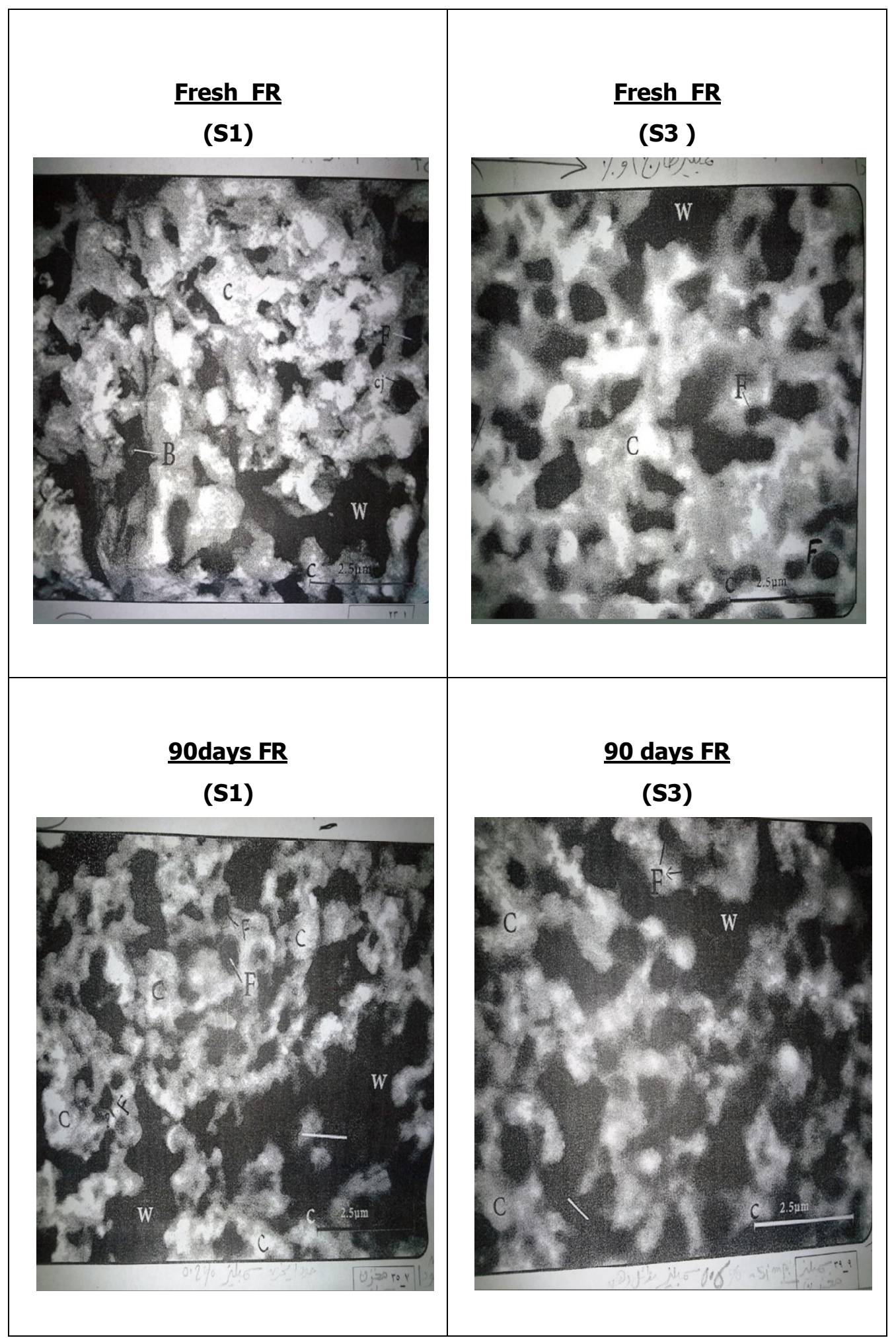

Fig. 2. Micrograph of fresh and 90 days low -fat Gouda- like cheese containing Simples $®-100,(0.2$, treatment S1) or $0.6 \mathrm{~g} /$ liter milk, treatment S3) . 


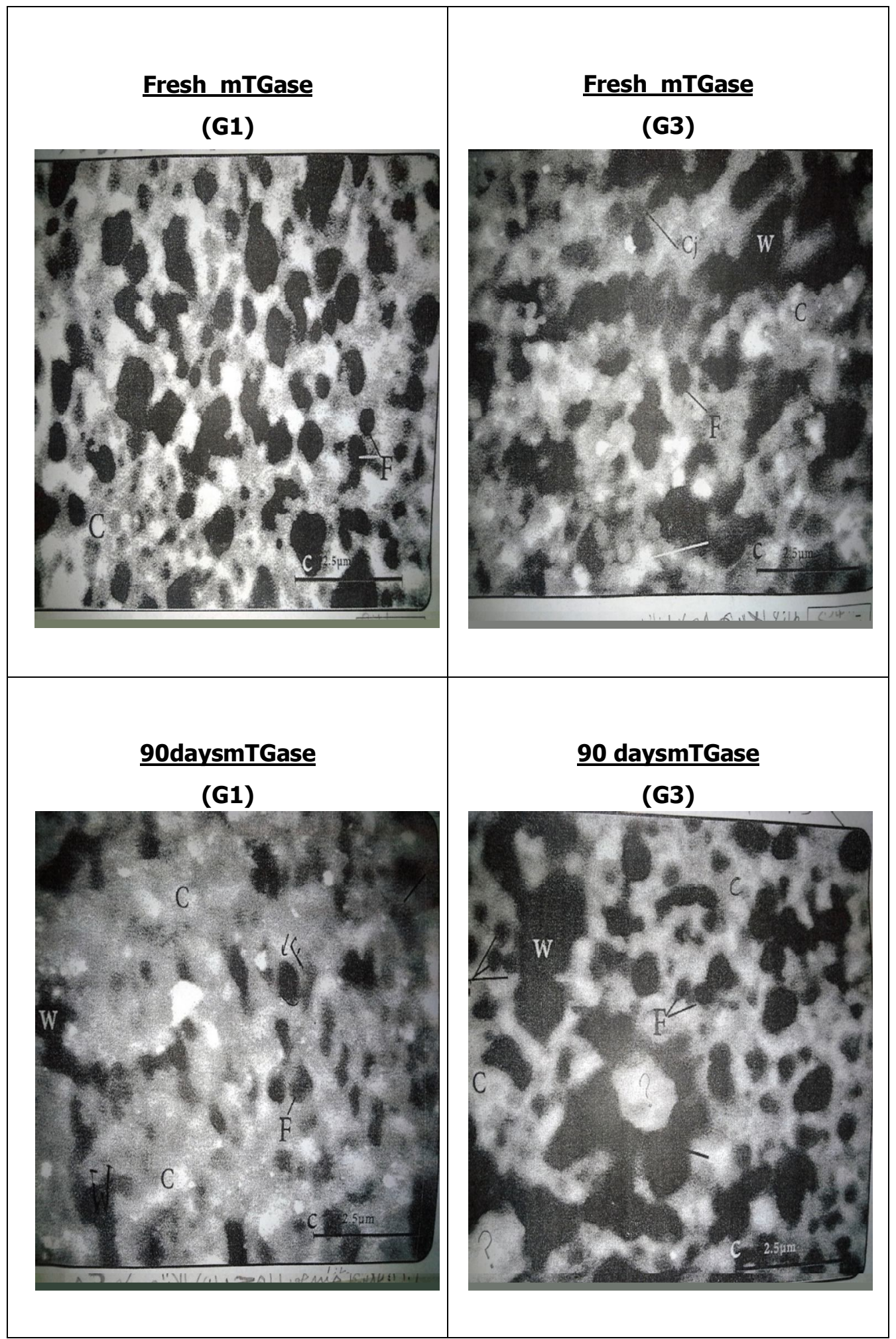

Fig. 3. Micrograph of fresh and 90 days low - fat Gouda - like cheese containing mTGase ( 0.3 , treatment $\mathrm{G} 1$ ) or $0.8 \mathrm{~g} /$ liter milk, treatment G3) . 


\section{Organoleptic properties:}

LFC (treatmentC2) was found inferior organoleptic ally than FFC (treatment C 1) especially in body $\&$ texture. LFC was characterized by firm body, impact texture and weak flavor. Addition of FR or mTGase improved greatly the former defects noticed in LFC. The higher level concentrations of the former additives (FR or mTGase) used were found the best.

\section{REFERENCES}

1. Abdel-Fattah, E.A. 1966. Studies on butter milk and its utilization in the manufacture of baby-Edam cheese. M.Sc. Thesis, Fac. of Agric., Ain Shams Univ., Egypt.

2. A.O.A.C. 2000.Official Methods of Analysis of the Association of OfficialAnalytical Chemists, $16^{\text {th }}$ Ed., Published by the Association of Analytical Virginia, 2220 USA.

3. Anderson, D.L. and V.V. Mistry. 1994. Reduced fat Cheddar cheese from condensed milk-2- Microstructure. J. Dairy Sci., 77:7.

4. Badawi, R.M.; Farag, I.S.; Okasha, A.I. and Omara, G.M. 2004. Changes in chemical composition and sensory properties of low-fat Mozzarella cheese during storage. Egyptian J. DairySci., 32(2):327-340.

5. Drake, L.MA, M.A.; G.V. Barbosa-Canovas and B.G.Swanson.1997. Rheology of full-fat and low-fat Cheddar cheeses as related to type of fat mimetic. J. Food Sci., 62: (4) 748-752.

6. El-Abd , M.M. ; Hayam M. Abbas; A.A. Mehriz; Hesham A. A.Eissa; A.A. El-Nimr, and HalaM.Bayoumi. 2010. Effect of ripening on some maturing parameters of

Egyptian Gouda Cheese. Journal of American Science. 2010;6(10):292295].ISSN: 1545-1003).

7. Fox, P.F.; Mc Sweeney, P.L.H; Cogan, T.M. and Guinee, T.P. 2004. Cheese Chemistry, Physics and Microbiology.Third Ed. Vol.1

a. General aspects. Elsevier Academic press. UK

8. IDF, 1993. Milk Determination of nitrogen content.IDF Standard No. 20B : internationonal Jornal Dairy Federation, Parts 1 and 2, IDF, Brussels, Belgium.

9. Karami, M.; Ehsani, M.R.; Mousavi, S.M.; Rezaei K. and Safari, M. 2009. Changes in the rheological properties of Iranian UF-Feta cheese during ripening. Food chem., $112: 539$.

10. Konkular, G.; G.E. Inglett, C.J.; Carriere, and F.C. Felker. 2004. Use ofbetaglucanhydrocolloidal suspension in the manufacture of low-fat Cheddar cheese: 
manufacture, composition, yield and microstructure. Inter. J. Food Sci. and Tech., 39(1):109-119.

11. Leuven,-1-Van; Caelenberg -T-Van, Dirinck -P. 2008. Aroma characterization of Gouda type cheeses.International Dairy Journal. (2008), 18 (8) 790 - 800.

12. Ling, E.R. 1963. " A text Book of Dairy Chemistry". Vol: II,Practical, $3^{\text {rd }}$ edition publishers Chapman and Hall Limited, London, UK,pp:76-98.

13. Michalski, M.C., Camier, B., Briard, V., Leconte, N., Gassi, J.Y., Goudedranche, H., Michel, F. and Fauquant, J. 2004. The size of native milk fat globules affects physico-chemical and functional properties of Emmental cheese. Lait, 84, 343-358343-358.

14. Mistry, V. V., 2001. Low-fat cheese technology. Int. Dairy J., 11: 413-422

15. Myllärinen,P.; Buchert, J. and Autio, K. 2007. Effect of transglutaminase on rheological properties and microstructure of chemically acidified sodium caseinate gels. Intr. Dairy J., 17: (7) 800-807.

16. Savello, P. A. and C. A. Ernstrom. 1989. Microstructure and meltability of model process cheese made with rennet and acid casein". J.Dairy Sci., 72:1.

17. Scott R., 1981. Cheese making practice. Elsevier, London, pp. 200.

18. Tamime,(2007).Structure of Dairy products. Blackwell Pu Publishing Ltd., 9600 Garsington Road, Oxford Ox42DQ, UK .

19. Ya-nan H., G. Ke-shan, g. Lu Jian, G. Hui-yuan, L. Jie, W. Fang and R. Fa-Zheng. 2013. Effect of transglutaminase on yield, compositional and functional properties of low - fat Cheddar cheese. Food Science. Technology Research, 19:359 - 367.

20. Zammar , O.A. 2000. Technological studies on Mozzarella cheese. pH. D .Thesis, Fac. of Agric. Ain Shams Univ. Egypt. 


\title{
التركيب الاقيق ، صورة الاحماض الدهنية ، التركيب الكيماوى و الصفات الحسية للجبن شبيه الجودا المنخفض الدهن خلال مدة التسوية
}

\author{
أمل مجاهد محمد النمر ، حاتم حلمى عمر، محمد على أحمد ، محمد أحمد مصطفى \\ قسم تكنولوجيا الألبان - معهد بحوث الأنتاج الحيوانى بالدقى - مركز البحوث الزراعية
}

يهرف هذا البحث الى دراسه نأثثر اضافة بديل الدهن ال Simples@-100, اوانزيم ال microbial Transglutaminase

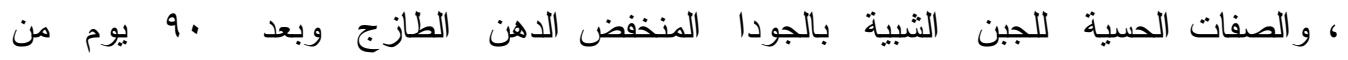

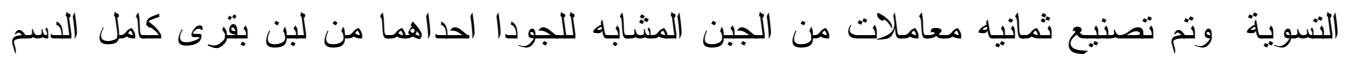
(1 (1, , . \% دهن) كعينه مقارنه (1) و السبع معاملات الأخرى تم تصنيعها من لبن منخفض الدهن

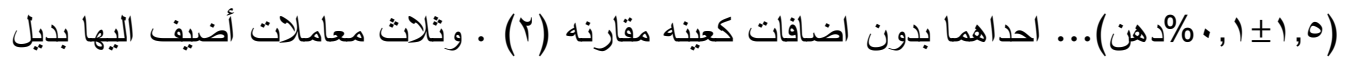

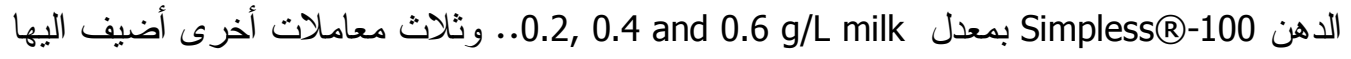

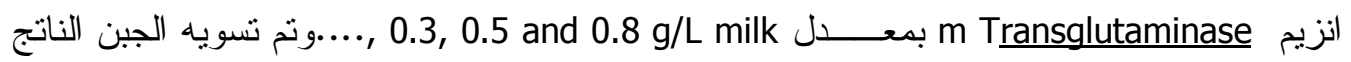

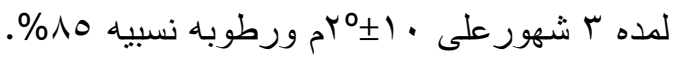

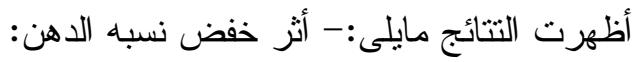

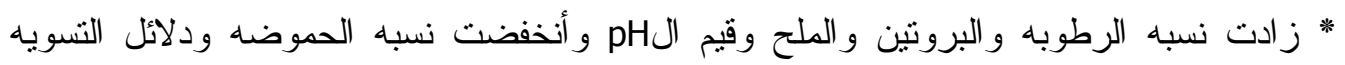

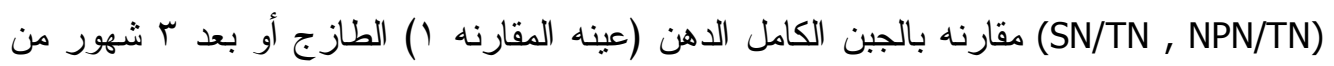

$$
\text { مده التسويه. }
$$

- زيادة تركيز الاحماض الدهنية الششبعة وخفض تركيز الاحماض الدهنية الغير مشبعة .

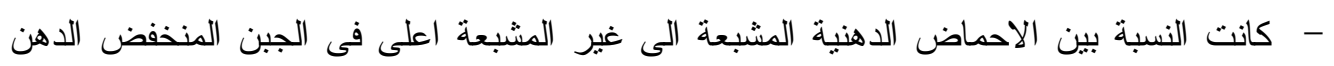

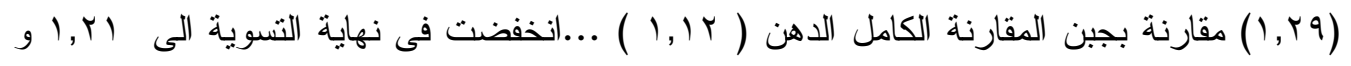

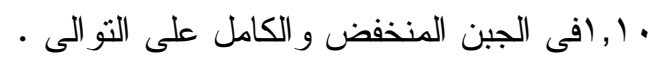

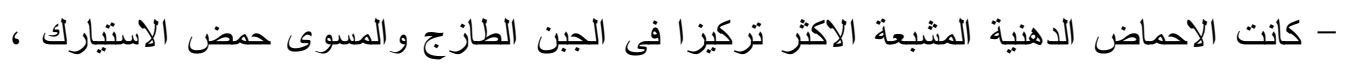

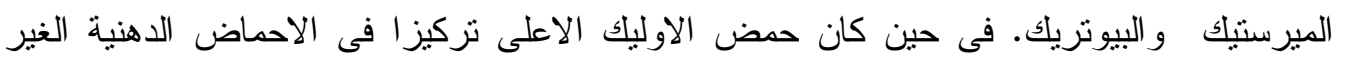
* تميز التزكيب الدقيق للجبن المنخفض الدهن بعدد قليل من الفجوات voids وكتلة بروتنين protein matrix 
اثر اضافة بديل الاهن,Simples@-100 او اتزيم ال mTransglutaminase :

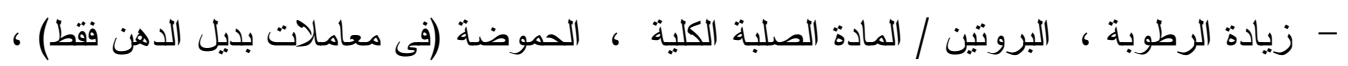

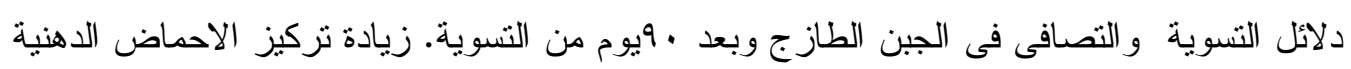

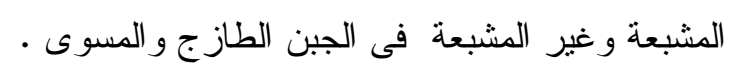

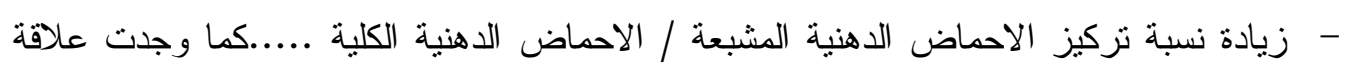

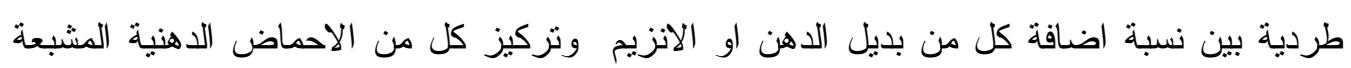
و غير المثبعة طو ال مدة التسوية. - تحسن التركيب الد قيق بدرجة كبيرة حيث تميز الجبن الطازج الناتج بتركيب مفتوح وفجوات اكثر تجانسا موحدة الثكل .....انتشار دقيق ومنظم لحبيبات الدهن فى كتلة البروتنين ...كتلة بروتين

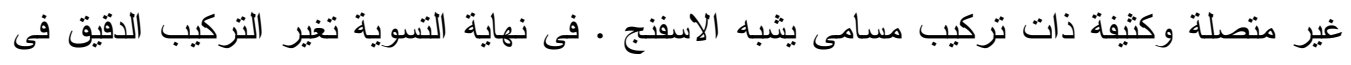

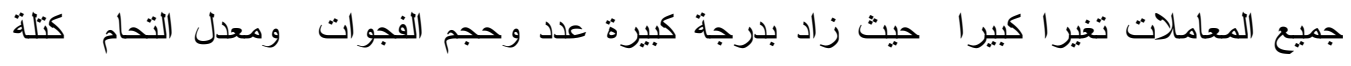
البروتين نتيجة للتفاعلات البيوكيميائية.

كان المظهر اقل شفافية فى جميع نركيزات بديل الدهن ...فى حين كان اكثر شفافية فى المعاملة

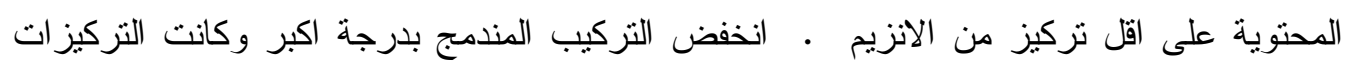

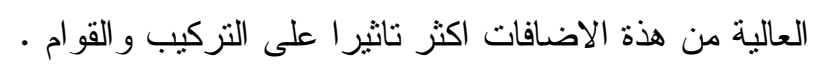

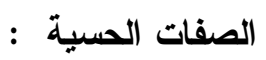

تميز الجبن المنخفض الدهن بصفات حسيية اقل من الجبن الكامل الدهن خصوصا فى القوام و التزكيب (قو ام صلب نوع ما وتركيب مندمج) ونكهة ضعيفة ـاضافة بديل الدهن او الانزيم حسن بدرجة كبيرة من هذة الصفات وعالج كثير من العيوب السابقة (خصوصا القو ام و التركيب) . ................ 
